\title{
Polar bear (Ursus maritimus) use of the Cape Bathurst polynya and flaw lead
}

\author{
Erin M. Henderson and Andrew E. Derocher
}

\begin{abstract}
The Cape Bathurst polynya and flaw lead (CBP) are major, predictable habitat features with $\leq 15 \%$ ice cover in an otherwise ice-covered Beaufort Sea, and thought to provide hunting opportunities for polar bears (Ursus maritimus Phipps, 1774). We assessed 78 adult (female; with and without cubs) and subadult (male and female) polar bears' use of the CBP from October to June 2007-2014. The CBP was up to $725 \mathrm{~km}$ wide in autumn, ice-covered in winter, and $<306 \mathrm{~km}$ wide in spring. Seventy-nine percent $(n=62)$ of the bears used the CBP $(\geq 1$ location $<2.4 \mathrm{~km}$, or one $4 \mathrm{~h}$ step length, from the CBP). Use was higher for solitary adult females and subadult males, which travelled faster with low turning angles along wider sections than females with offspring and subadult females. Bears were closest to the CBP during the spring hyperphagia season. Although a wider CBP did not prevent crossing, bears primarily crossed from the coast towards pack ice at locations $53 \%$ narrower than areas not crossed. Bears might avoid crossing when it would require a long-distance swim. The CBP affects polar bear ecology by providing hunting habitat and a corridor that could increase prey encounters but may affect movement.
\end{abstract}

Key words: Cape Bathurst polynya, flaw lead, Ursus maritimus, Beaufort Sea, first passage time.

Résumé : La polynie et le chenal de séparation du Cap Bathurst (PCB) sont des caractéristiques majeures et prévisibles d'un habitat ayant une couverture de glace de $\leq 15 \%$ dans une mer de Beaufort autrement couverte de glace, et on pense qu'ils offrent des opportunités de chasse aux ours polaires (Ursus maritimus Phipps, 1774). Les auteurs ont évalué l'utilisation du PCB par 78 ours polaires adultes (femelles, avec ou sans oursons) et subadultes (mâles et femelles) d'octobre à juin, de 2007 à 2014. Le PCB avait une largeur allant jusqu'à $725 \mathrm{~km}$ en automne, était recouvert de glace en hiver et avait une largeur de $<306 \mathrm{~km}$ au printemps. Soixante-dix-neuf pour cent $(\mathrm{n}=62)$ des ours ont utilisé le PCB ( $\geq 1$ emplacement $<2,4 \mathrm{~km}$, ou une longueur d'étape de $4 \mathrm{~h}$ du PCB). L'utilisation était plus élevée pour les femelles adultes solitaires et les mâles subadultes, qui se déplaçaient plus rapidement avec des angles de virage faibles le long de sections plus larges que les femelles avec leur progéniture et les femelles subadultes. Les ours étaient plus proches du PCB pendant la saison d'hyperphagie du printemps. Bien qu'un PCB plus large n'ait pas empêché la traversée, les ours l'ont principalement traversé de la côte vers la banquise à des endroits $53 \%$ plus étroits que les zones non traversées. Les ours peuvent éviter de traverser lorsque cela nécessite une longue distance à la nage. Le PCB affecte l'écologie de l'ours polaire en fournissant un habitat de chasse et un corridor qui pourrait accroître les rencontres avec les proies, mais affecter les déplacements. [Traduit par la Rédaction]

Mots-clés : polynie du Cap Bathurst, chenal de séparation, Ursus maritimus, Mer de Beaufort, temps du premier passage.

Received 13 May 2021. Accepted 3 September 2021.

E.M. Henderson and A.E. Derocher. Department of Biological Sciences, University of Alberta, Edmonton, AB T6G 2E9, Canada.

Corresponding author: Erin M. Henderson (email: ehenders@ualberta.ca).

() 2021 The Author(s). This work is licensed under a Creative Commons Attribution 4.0 International License (CC BY 4.0), which permits unrestricted use, distribution, and reproduction in any medium, provided the original author(s) and source are credited. 


\section{Introduction}

Polynyas are recurrent areas that are predominantly or completely ice-free in an area otherwise ice-covered (Smith et al. 1990), whereas flaw leads are recurrent, linear ice-free areas between landfast ice and pack ice (Barber and Massom 2007). They occur throughout the Arctic and are ecologically important due to their high primary productivity and provision of habitat to a diversity of species (Stirling 1980; Arrigo and van Dijken 2004; Laidre et al. 2008). The Cape Bathurst polynya and flaw lead system (CBP) is a productive component of the Beaufort Sea located in the western Canadian Arctic that extends westwards into Alaska (Smith and Rigby 1981; Carmack and MacDonald 2002). Landfast ice in this area extends offshore to the $20 \mathrm{~m}$ isobath beyond which the flaw polynya is an area of dynamic ice cover bounded to the north by drifting pack ice (Carmack and MacDonald 2002). The CBP is habitat for many resident and migratory marine species include sea ducks, seals, whales, and polar bears (Ursus maritimus Phipps, 1774) (Stirling et al. 1981; Gilchrist and Robertson 2000; Citta et al. 2015; Mallory et al. 2019).

Polynyas have been postulated as important habitat for polar bears (Stirling 1980; Stirling 1997). In the Beaufort Sea, the floe edge near the CBP is preferred habitat for some age and sex classes of bears (Stirling et al. 1993) but rigorous assessment is limited. Polynyas occur near shallow water where the primary prey of polar bears, ringed seals (Pusa hispida Schreber, 1775) and bearded seals (Erignathus barbatus Erxleben, 1777; Pilfold et al. 2014b; Florko et al. 2020b), are abundant (Stirling et al. 1977; Frost et al. 2004; Breed et al. 2018). In Hudson Bay, the flaw lead acted as a corridor that was suggested to increase prey encounters, but in contrast, wider areas of the lead may have deterred crossing and, thus, acted as a barrier (Henderson et al. 2021). Despite polynyas being a significant component of Arctic ecosystems their importance for polar bears remains poorly studied.

We investigated polar bear use and selection of the CBP, and how bear movements changed relative to the CBP using satellite telemetry data. We compared these metrics between reproductive groups, and at different times of the year. We hypothesized that bears would be attracted to the CBP in spring due to access to prey, particularly solitary adult females and subadult males who select for higher quality habitat. Based on Henderson et al. (2021), we predicted bears would use the CBP to hunt, which would be reflected in faster movements along the CBP with lower turning angles. We predicted width of the CBP would not inhibit crossing as Beaufort Sea bears frequently undergo long distance ( $>50 \mathrm{~km}$ ) swims (Pagano et al. 2012; Pilfold et al. 2017), however, bears may be more likely to remain in higher quality pack ice.

\section{Materials and Methods}

\section{Study area and subpopulation}

The Beaufort Sea has a narrow continental shelf $<110 \mathrm{~km}$ wide with deep water farther offshore in the Canada Basin (Sharma 1979; Carmack and MacDonald 2002). Freeze-up begins in October/November, and break-up begins in May (Smith and Rigby 1981; Johnson and Eicken 2016). The CBP forms in the Amundsen Gulf between Baillie Island and Banks Island (Stirling 1980; Smith and Rigby 1981) with the associated flaw lead extending northward and westward (Fig. 1) and can be open any time there is ice cover, but is most prominent beginning in April (Smith and Rigby 1981). Polar bears are found throughout the Beaufort Sea and Amundsen Gulf and are part of the Southern Beaufort Sea and Northern Beaufort Sea subpopulations (Stirling et al. 2011; Bromaghin et al. 2015). Approximately $73 \%$ of bears remain on sea ice year round, moving north beginning in June following the retreating ice pack as it breaks up, however, some bears move onto land for the autumn until freeze-up (Schliebe et al. 2008; Pongracz and Derocher 2017). 
Fig. 1. Study area maps showing (A) the Beaufort Sea and Amundsen Gulf, including the location of collar deployments and the location of the Cape Bathurst polynya and flaw lead (CBP) on 1 November 2010; and (B) the distance categories for 1 November 2010. The CBP was mapped using AMSR-E, AMSR2, and SSMIS imagery (Spreen et al. 2008). The dashed line represents the on-ice 100\% minimum convex polygon for Beaufort Sea polar bears from October to May 2007-2014. Distance categories, On, Near, and Off the CBP are shown for 1 November 2010. Habitat $\leq 1$ median step length from the CBP was considered to be "on" the CBP (dark grey), habitat $>1$ median step length but $\leq 2$ times median daily displacement was considered "near" the CBP (medium grey), and habitat $>2$ times median daily displacement was considered "off" the CBP (light grey). The figures were made in QGIS Version 3.10 using a basemap obtained from (Sandvik 2009) and projected in UTM NAD83 Yukon Albers, EPSG: 3578.
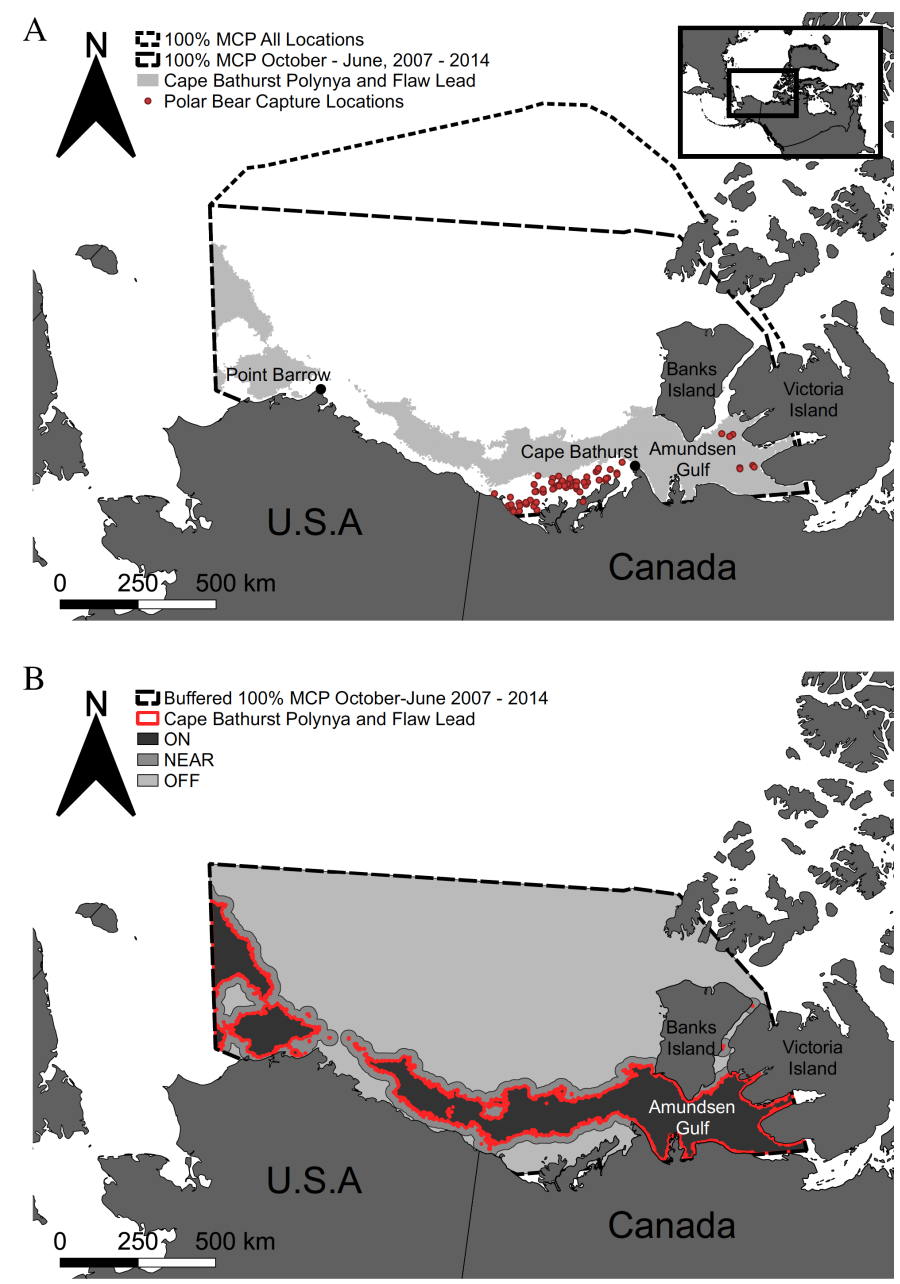

\section{Polar bear telemetry}

Following standard protocols (Stirling et al. 1989), male and female subadult (2-4 years old) and female adult ( $\geq 5$ years old) polar bears from the Beaufort Sea population were immobilized by remote injection of tiletamine hydrochloride and zolazepam hydrochloride (Zoletil ${ }^{\circledR}$, Virbac, Carros, France). Ages were determined from a vestigial premolar extracted at capture (Calvert and Ramsay 1998) or by tooth eruption for dependent offspring. Bears were caught from April to May of 2007 to 2011 along the Canadian coast of the Beaufort Sea, and from April to May 2012 in Amundsen Gulf (Fig. 1A). Bears were 
fitted with geographic positioning system (GPS) Argos ${ }^{\circledR}$ satellite-linked collars (accuracy $30 \mathrm{~m}$; Telonics Inc., Mesa, Arizona, USA; Tomkiewicz et al., 2010) with locations every $4 \mathrm{~h}$ from May 2007 to December 2014. Collars were equipped to drop off via either a timedrelease mechanism (CR2a, Telonics, Mesa, Arizona, USA) after 1 year for subadults, or 2 years for adults, or via a corrodible link, or collars were removed upon recapture. Animal capture and handling procedures were approved by the University of Alberta BioSciences Animal Care and Use Committee (Protocols 409705, 600804, 600904, 6001004) in accordance with Canadian Council on Animal Care wildlife guidelines (www.ccac.ca/Documents/Standards/ Guidelines/Wildlife.pdf). Research was conducted under Government of Northwest Territories Department of Environment and Natural Resources permits (WL003322, WL005372, WL005596, WL007376).

Ice drift vectors were removed from bear movement vectors to measure voluntary movement using Polar Pathfinder Daily $25 \mathrm{~km}$ EASE-Grid Sea Ice Motion Vectors from the National Snow and Ice Data Center (Tschudi et al. 2019), following Auger-Méthé et al. (2016) and Togunov et al. $(2017,2018)$. Temporal and spatial interpolation via inverse distance weighting (Li and Heap 2011) was used to determine ice drift at bear locations. We used a WGS 84/NSIDC Sea Ice Polar Stereographic North (EPSG:3413) projection (https://epsg.io/3413) for telemetry locations.

Bear sex and presence and age of offspring was recorded at capture and inferred for the tracking period following Johnson and Derocher (2020) and Henderson et al. (2021). Reproductive status included: male subadult, female subadult, solitary adult female, accompanied by cub(s)-of-the-year (COY), and accompanied by yearling(s) or 2-yr-old offspring (YRLG). When females with COY and YRLG had the same results, they were grouped together as females with offspring. Bears with on-ice movements that matched ice drift (Togunov et al. 2020) from November-March were presumed to be denning on sea ice, and stationary bears on land from November-April were presumed to be denning on land (Amstrup and Gardner 1994). Denning bears were inferred to be solitary for the previous breeding season and autumn (March-June; October-enter den) with COY for the following year (Lønø 1970; Ramsay and Stirling 1986). Offspring typically remain with their mothers for 2.5 years (Ramsay and Stirling 1986; 1988), therefore, females with COY were presumed to have YRLG and females with YRLG were presumed to have 2-yr-old offspring by March-June of the following year, and females with 2-yr-olds in spring were presumed to be solitary by October.

\section{Telemetry data filtering}

Telemetry locations with biologically impossible speeds ( $>10 \mathrm{~km} \mathrm{~h}^{-1}$; Amstrup et al. 2000, Parks et al. 2006), or turning angles of $>165^{\circ}$ or $>155^{\circ}$ that were $>25 \mathrm{~km}$ or $>50 \mathrm{~km}$ from the previous and subsequent location respectively were removed using the "argosfilter" R package (Freitas 2012). Missing locations were estimated if the time between subsequent locations was $>4 \mathrm{~h}$ but $\leq 24 \mathrm{~h}$ by fitting a continuous-time correlated random walk (CRAWL) model with the Kalman-filter using the "crawl" $\mathrm{R}$ package (Johnson et al. 2008; Johnson and London 2018). Telemetry locations on land, and following Togunov et al. (2020) from dropped collars on sea ice, were removed. Locations from presumed ice-denning bears were also removed from analysis until voluntary movement resumed. Telemetry locations outside of the western most extent of the Southern Beaufort Sea subpopulation boundary were removed.

Freeze-up and break-up were defined based on sea ice concentration from Advanced Microwave Scanning Radiometer-Earth Observing System (AMSR-E \& AMSR2; resolution $3.125 \mathrm{~km}$; Spreen et al. 2008) from May 2007 to September 2011 and September 2012 to December 2014, and Special Sensor Microwave Imager/Sounder (SSMIS; resolution $3.125 \mathrm{~km}$; Spreen et al. 2008) from October 2011 to August 2012. Ice concentration was 
averaged using the "raster" $R$ package in R version 3.6.1 (Hijmans 2019b; R Core Team 2019) over the $100 \%$ minimum convex polygon (MCP) calculated with the "adehabitatHR" R package (Calenge 2006) using all bear locations from May 2007 to December 2014 (Fig. 1A). Following (Johnson and Eicken 2016), break-up began when sea ice concentration was below the mean January-February concentration minus two standard deviations and did not increase above this threshold until the following freeze-up. Break-up ended when the ice concentration was below the mean August-September concentration plus one standard deviation and did not increase above this threshold until the following freeze-up. Freeze-up began when the ice concentration was above the mean August-September ice concentration plus one standard deviation and did not decrease below this threshold until the following breakup. Freeze-up ended when the ice concentration was above the mean January-February ice concentration minus two standard deviations and did not decrease below this threshold again until the following breakup. Analyses examined the period when the study area was three quarters through freeze-up (approximately late October/ early November), and ended when it was one quarter through break-up (approximately late March - mid June; Table S1 in Supplementary material $1^{1}$ ).

\section{CBP dynamics}

We mapped the CBP based on sea ice concentration from AMSR-E, AMSR2, and SSMIS imagery (Spreen et al. 2008). We used a sea ice concentration threshold of $\leq 15 \%$ to represent water (Heinrichs et al. 2006), and identified all water using the "raster" and "rgeos" R packages (Bivand and Rundel 2019; Hijmans 2019b), and geoprocessing tools in QGIS version 3.4.5 (QGIS Development Team 2019). The ice imagery extended outside the Beaufort Sea, so to limit the extent of water to what was biologically relevant to a bear, we defined the CBP as the presence of water within a buffered composite home range of all bears. The composite home range was calculated as the 100\% MCP of all bears within the study period. The extent of the buffer was equivalent to two times the median daily displacement of all bears and years pooled (Fig. 1A). Bears' use, selection, and movements might be influenced by water just outside their composite home range; therefore, buffering the home range allowed us to detect this influence. Daily displacement was the sum of the distance between 6 consecutive $4 \mathrm{~h}$ locations within one day with the ice drift component removed. Median daily displacement of all bears and years was calculated using all days within the study with 6 locations/day.

We calculated the total area of the CBP per day using the "raster" $\mathrm{R}$ package (Hijmans 2019b). The width of the CBP was the straight-line distance from point A to point B across each polygon of the CBP beginning from every vertex (Fig. 2) using the "rgeos" and "geosphere" R packages (Bivand and Rundel 2019; Hijmans 2019a). We used the mean across all polygons to calculate the daily mean, and the maximum daily width of the CBP. We fit broken stick regressions to determine breakpoints in the relationship between the ordered date (continuous count of days from the first day of the study year in October/November to the last day in May/June) and the maximum width, mean width, and total area of the CBP in R (Muggeo 2003, 2008, 2016, 2017). We then fit generalized linear models (GLM) to assess the temporal trends in the maximum and mean width and total area of the CBP in R (Bates et al. 2015). Predictor variable significance was assessed at $\alpha=0.05$. Breakpoint values are presented in Supplementary material $2^{1}$.

\footnotetext{
${ }^{1}$ Supplementary data are available with the article at https://doi.org/10.1139/as-2021-0023.
} 
Fig. 2. Example of calculating the width of the Cape Bathurst polynya and flaw lead. We measured width as the straight-line distance from point A directly across to point $B$. To find the maximum and mean width, we found the width at every vertex of each polygon, and found the maximum and mean across all polygons, respectively, for each day, and each polygon beginning at point A and ending at point B. The width closest to the Beaufort Sea polar bears' position was calculated in the same manner. The figure was made in QGIS Version 3.10 using a basemap obtained from (Sandvik 2009) and projected in UTM NAD83 Yukon Albers, EPSG: 3578.

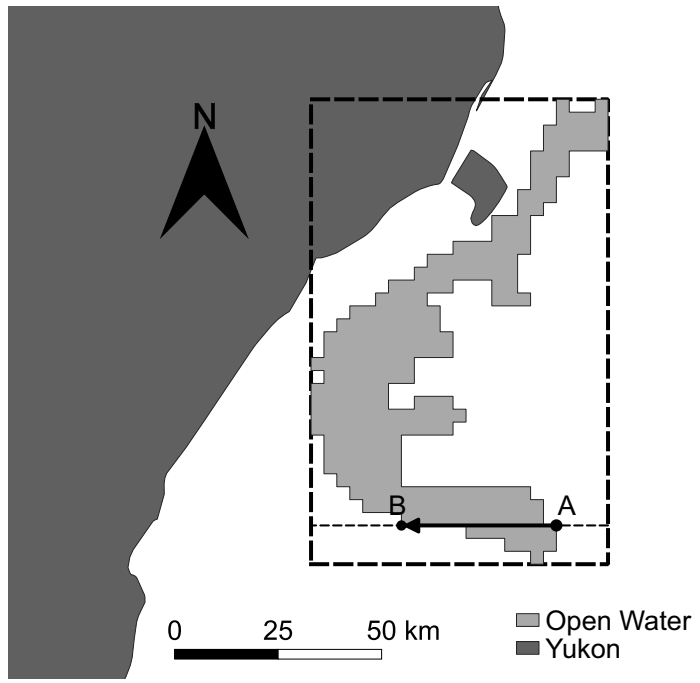

Table 1. Maximum likelihood linear mixed effects (LME) and generalized linear mixed effects (GLME) models by dependent variable predicting polar bear use, selection, and movements relative to the Cape Bathurst Polynya and flaw lead (the CBP) from October to June 2007-2014.

\begin{tabular}{|c|c|c|c|c|}
\hline Dependent variable & $\begin{array}{l}\text { Space-use } \\
\text { analysis }\end{array}$ & $\begin{array}{l}\text { Data } \\
\text { subset }\end{array}$ & $\begin{array}{l}\text { Model } \\
\text { type }\end{array}$ & Covariates \\
\hline Ice concentration & Use & Oct-Jun & GLME & Distance to CBP \\
\hline Ice concentration & Use & On CBP & LME & Width closest to bear \\
\hline Distance to CBP/coast & Use & Oct-Jun & LME & $\begin{array}{l}\text { Ordinal date; maximum daily width; mean daily } \\
\text { width; total daily CBP area; reproductive status } \\
\text { (SOL, YRLG, COY, SUB_F, SUB_M) }\end{array}$ \\
\hline CBP use & Selection & On CBP & GLME & Width \\
\hline Crossing rate & Movement & On CBP & GLME & $\begin{array}{l}\text { CBP side; mean width; ordered date; reproductive } \\
\text { status (SOL, YRLG, COY, SUB_F, SUB_M) }\end{array}$ \\
\hline First passage time & Movement & Oct-Jun & LME & $\begin{array}{l}\text { Ordered date; distance to CBP; reproductive status } \\
\text { (SOL, YRLG, COY, SUB F, SUB M) }\end{array}$ \\
\hline First passage time & Movement & On CBP & LME & $\begin{array}{l}\text { Width; reproductive status (SOL, YRLG, COY, } \\
\text { SUB_F, SUB_M) }\end{array}$ \\
\hline
\end{tabular}

Note: Bears were on the CBP when within one median step length $(2.4 \mathrm{~km})$ from the CBP. The covariates listed for each model were tested individually, and in combination with other non-correlated variables to generate sets of candidate models. SOL, solitary female; YRLG, females with yearling(s); COY, females with cub(s)-of-the-year; SUB_F, subadult female; and SUB_M, subadult male. Width $(\mathrm{km})$ was the width at the point closest to the bear.

\section{CBP use and selection}

We examined bears' use (in three analyses) and selection (in one analysis) of the CBP and ice concentrations (Table 1). First, we stratified the buffered composite home range into 3 distance categories (Fig. 1B): "on" ( $\leq 1$ median step length from the CBP), "near" ( $>1$ median step length, $\leq 2$ times median daily displacement from the CBP), and "off" ( $>2$ times median daily displacement from the CBP). Step length was the distance between two consecutive 
$4 \mathrm{~h}$ locations with the ice drift component removed (Henderson et al. 2021). Median step length was calculated using consecutive $4 \mathrm{~h}$ locations for all bears and years. We used $\chi^{2}$ tests $(\alpha=0.05)$ to estimate use, based on the number of bear locations within distance categories, determined by bears' distance to the CBP, relative to availability based on areal extent of the CBP. Bears' distance to the CBP was the shortest straight-line distance from the bear location to the CBP. The number of locations within each distance category was also compared by reproductive status and month. Adjusted standardized residuals identified the distance category with a disproportionate number of locations (Agresti 2018).

Second, we examined use of the CBP by predicting bears' distance to the CBP based on maximum daily width, mean daily width, total daily CBP area, quadratic ordered date, and reproductive status, with a random effect for individual (Table 1) on days with open water. To examine whether bears moved towards the CBP to use it, or whether the edge of the CBP moved closer to the bears, we also predicted bears' distance to the coast based on maximum daily width, mean daily width, total daily CBP area, quadratic ordered date, and reproductive status, with a random effect for individual (Table 1). Distance to coast was the shortest straight-line distance from the bear location to the closest point on the North American coast. We fit linear mixed effects (LME) models to predict bears' distance to the CBP; distance to the CBP was square root transformed to normalize residuals. We fit generalized linear mixed effects (GLME) models to predict bears' distance to coast. Quadratic ordered date was used in candidate models because it provided a better fit than ordinal date or months. Ordered date and reproductive status were tested both individually and as an interaction.

Third, we examined ice concentration used by bears based on bears distance to the CBP and on the width of the CBP as a measure of habitat quality. We fit GLME models with a binomial link and individual as a random effect to predict ice concentration used based on distance to the CBP (Table 1). Ice concentration at a bear's location was extracted from AMSR-E, AMSR2, and SSMIS imagery (Spreen et al. 2008). We then fit two sets of maximum likelihood, LME models to predict the ice concentration used by bears based on the CBP width (width) closest to the bear when bears were on the CBP. Top models were selected using corrected Akaike information criterion values corrected for sample size ( $\mathrm{AIC}_{\mathrm{c}}$ ), with the most parsimonious model chosen when $\Delta \mathrm{AIC}_{\mathrm{c}}$ was $<2$ (Burnham and Anderson 2002).

We examined bear selection of the CBP based on width by fitting GLME models with a random effect for individual in a used and available design (Table 1). We used the "on" category for each day with bear locations to generate 100 random locations representing available habitat and compared them with bear locations within the "on" category. Widths closest to the bear locations and random locations were the shortest straight-line distance across the CBP starting from the point on the CBP closest to the bears' or random location (Fig. 2). Width was tested as both a linear and quadratic variable based on initial visual inspection of the relationship.

We used Spearman's rank correlation to exclude correlated predictor variables $(r>|0.6|)$ from the same candidate models. Candidate models with $\mathrm{AIC}_{\mathrm{c}}$ values are presented in Supplementary material 3-5 ${ }^{1}$.

\section{Bear movements}

We calculated four metrics (relative movement direction, turning angles, crossing rate, and first passage time) to examine how date, reproductive status, distance to the CBP, and CBP width affected bear movement (Table 1). We assessed bear movements to examine how they responded to and used the CBP, and whether it posed a barrier to movement. First, to examine how bears' movements responded to the CBP, we examined changes in bears' direction of travel as they approached the CBP by calculating their relative 
movement direction and turning angles to determine if their movements were random relative to the $\mathrm{CBP}$ within each distance category for each reproductive group. Relative movement direction is the direction of bears' overall movement relative to the CBP, and was the angle $\left(-180^{\circ} \leq \theta \leq 180^{\circ}\right)$ between the straight line connecting two consecutive GPS locations, and the shortest straight line from the initial location to the CBP (McKenzie et al. 2012; Henderson et al. 2021). We categorized relative movement directions as towards $\left(-45^{\circ} \leq \theta \leq 45^{\circ}\right)$, along $\left(-45^{\circ}>\theta>-135^{\circ}\right.$ and $\left.45^{\circ}<\theta<135^{\circ}\right)$, or away from $\left(-135^{\circ} \leq \theta \geq 135^{\circ}\right)$ the CBP. Turning angles $\left(-180^{\circ} \leq \theta \leq 180^{\circ}\right)$ represent the change in direction from the lines connecting three consecutive GPS locations (Henderson et al. 2021) and was calculated on tracks consisting of voluntary, consecutive $4 \mathrm{~h}$ locations excluding those interpolated by CRAWL using the "trajr" R package (McLean and Skowron Volponi 2018). GPS error can result in erroneous large turning angles in stationary bears (Hurford 2009); therefore, locations $\leq 30 \mathrm{~m}$ from the previous location were removed. We categorized turning angles as low $\left(-45^{\circ} \leq \theta \leq 45^{\circ}\right)$, turn $\left(-45^{\circ}>\theta>-135^{\circ}\right.$ and $\left.45^{\circ}<\theta<135^{\circ}\right)$, or reversal turn $\left(-135^{\circ} \leq \theta \geq 135^{\circ}\right)$. We used a $\log$ likelihood ratio test with a $\chi^{2}$ distribution $(\alpha=0.05)$ to test whether the distributions of relative movement directions and turning angles best fit a uniform distribution, or a univariate or bivariate von Mises distribution, calculated using the "circular" R package (Agostinelli and Lund 2017).

Second, to examine how bear movements responded to the CBP as an indication of space-use, we calculated first passage time (FPT) to quantify changes in movement paths relative to a bear's distance to the CBP. FPT measures the amount of time for a bear to cross a circle of a fixed radius centered on their location, giving an estimate of how quickly a bear is moving through an area (Fauchald and Tveraa 2003; 2006). The radius of area-restricted search (ARS), a foraging pattern used by animals following prey encounters whereby they reduce movement rates and/or increase turn frequency to remain in the area, is the optimal radius to differentiate between areas of high and low FPT (Fauchald and Tveraa 2003; Freitas et al. 2008). To find the radius of ARS, we followed Fauchald and Tveraa (2003, 2006), and used the "adehabitatLT" $R$ package (Calenge 2006), to interpolate locations at $2 \mathrm{~km}$ intervals along the length of voluntary movement tracks consisting of at least 33 consecutive $4 \mathrm{~h}$ locations. Using radii ranging from $500 \mathrm{~m}$ to $100 \mathrm{~km}$ at $500 \mathrm{~m}$ intervals, we calculated FPT of the equally spaced tracks to find the peak mean variance in $\log _{10^{-}}$ transformed FPT and the corresponding radius, which is the radius of ARS (Fauchald and Tveraa 2003). We calculated FPT on original voluntary movement tracks using the radius of ARS for all bears and years.

We fit LME models with a random effect for individual to predict $\log _{10}$-transformed FPT based on quadratic ordered date, reproductive status, distance to the CBP, and width (Table 1) for days with open water. Distance to the CBP was included as both linear and quadratic variables and ordered date and reproductive status were tested individually and as interaction terms. To account for autocorrelation, we removed FPTs when the distance between locations was less than the radius of ARS (Freitas et al. 2008). Candidate models were fit for two subsets of data: FPT from October to June with ordered date, reproductive status, and distance to the CBP as predictor variables; and FPT when bears were on the $\mathrm{CBP}$ with reproductive status and width closest to the bear as predictor variables and both populations combined due to small sample size. We compared candidate models using a model selection criterion of $\Delta \mathrm{AIC}_{\mathrm{c}}<2$ (Supplementary material $\left.6^{1}\right)$. Results are presented with mean \pm SE unless stated otherwise.

We explored the CBP as a barrier to bear movement by characterizing movements in the "on" distance category based on whether the bear crossed the CBP. Bear tracks were divided into trips, which consisted of consecutive locations within the "on" category and ended when the bear moved into the "near" category (Henderson et al. 2021). A crossing occurred 
when a trip began on the side of the CBP closest or farthest from the coast, and finished on the opposite side, and was visually confirmed in QGIS using MODIS imagery from the National Aeronautics and Space Administration WorldView database when available (NASA 2018; QGIS Development Team 2019). Each trip was assigned a response of 1 or 0 based on whether it crossed the CBP or not, respectively. We fit GLME models to predict CBP crossing based on mean width, quadratic ordered date, and the side of the CBP trips began on ( 2 categories: side closest or farthest from the coast) as predictor variables, with a random effect for individual (Table 1). We compared candidate models using a model selection criterion of $\Delta \mathrm{AIC}_{\mathrm{c}}<2$ (Supplementary material $7^{1}$ ).

\section{Results}

Polar bear telemetry

The study began in mid-May 2007, after the first bears were collared, and ended in late December 2014. With the exception of the first and last year, each study year began in late October/early November and ended in mid-late May/June (Table S1 in Supplementary material $1^{1}$ ). The mean telemetry tracking period was 1.1 years \pm 0.1 (range: $<1-4.1$ years, $n=78$ bears) from 2007 to 2014 . At least once over the deployment, 30 bears were solitary, 21 with COY, 37 with YRLG, 12 were subadult female, and 10 were subadult male. Collars provided 139150 locations, of which $110(0.08 \%)$ were removed due to biologically impossible speeds. The time between locations in tracks with $4 \mathrm{~h}$ consecutive locations before interpolation was $4.7 \pm 0.01 \mathrm{~h}$. Interpolated tracks contained $15.2 \pm 0.4 \%(0 \%-50 \%$; $\left.n_{\text {tracks }}=1024\right)$ interpolated points, with a mean interpolated time gap of $10.7 \pm 0.05 \mathrm{~h}$ (8-24 h).

\section{CBP dynamics}

Eleven days were missing ice imagery and were excluded from analysis. The CBP was present on $70 \%$ of the days (1129 out of 1613 days). The mean number of consecutive days when the CBP was closed (no open water) was $0.4 \pm 0.1$ days (range: 0-62 days). The mean maximum width on all days was $68 \pm 3 \mathrm{~km}$ (range: $0-725 \mathrm{~km}$ ), and only on days when open water was present was $97 \pm 4 \mathrm{~km}$ (range: $3-725 \mathrm{~km}$ ). The mean width on all days (with and without open water) was $22 \pm 1 \mathrm{~km}$ (range: $0-226 \mathrm{~km}$ ), and only on days with open water, the mean width was $31 \pm 1 \mathrm{~km}$ (range: $3-226 \mathrm{~km}$ ). The mean CBP total area on all days (with and without open water) was $2.3 \times 10^{4} \pm 1.4 \times 10^{3} \mathrm{~km}^{2}$ (range: $0-5.2 \times 10^{5} \mathrm{~km}^{2}$ ), and only on days with open water, the CBP was $3.3 \times 10^{4} \pm 1.9 \times 10^{3} \mathrm{~km}^{2}$ (range: $10-5.2 \times 10^{5} \mathrm{~km}^{2}$ ). The CBP was widest and had the greatest total area at the beginning and end of the study year (Fig. 3, Fig. S1 in Supplementary material $2^{1}$ ).

\section{CBP use and selection}

The median step length was $2.4 \pm 0.1 \mathrm{~km}(n=76733)$, and the median daily displacement was $12 \mathrm{~km}(n=71772)$. Bears were on the CBP for $2 \%$ of the locations $(n=1252)$, near for $11 \%$ of the locations ( $n=6274)$, and off for $87 \%$ of the locations $(n=49916)$.

Bears had a higher proportion of locations near and on, and lower proportion of locations off the CBP relative to the amount of habitat available in each category. Females with offspring, and subadult females were more frequently near the CBP than expected based on available area, and less frequently on or off the CBP (Table 2). Solitary adult females and subadult males were more frequently near and on the CBP, and less frequently off than expected (Table 2). Bears were on and near the CBP most frequently in June, and off most frequently in November (Table 2).

Bears used ice closest to the CBP at the beginning and end of the study year (Fig. 4A). We found significant differences in use based on reproductive status. At a mean daily 
Fig. 3. Predicting Cape Bathurst Polynya and flaw lead maximum width $(\mathrm{km})$ October to June 2007-2014. The red line represents the predicted trends, whereas the dots represent the observed values. Data were based on AMSRE, SSMIS, and AMSR2 satellite imagery (Spreen et al. 2008) from October to June 2007-2014.

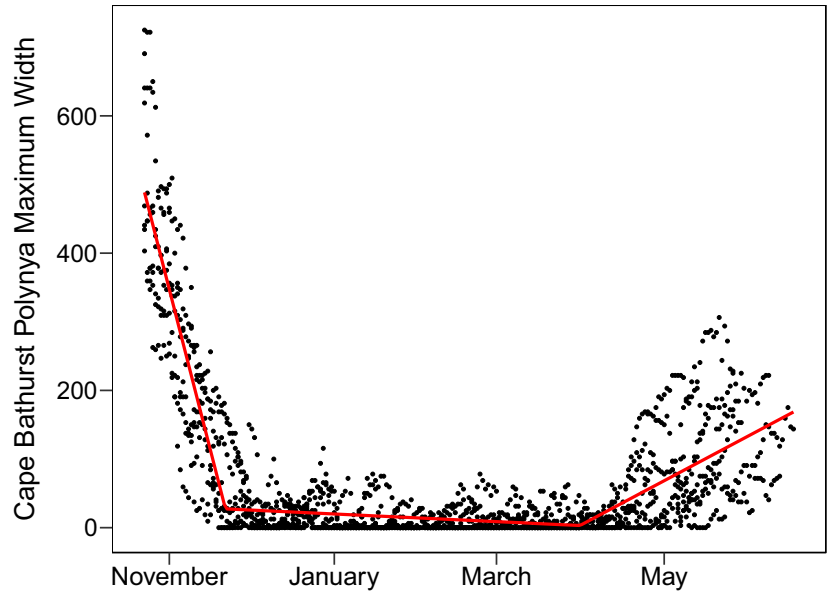

Table 2. Standardized residuals of $\chi^{2}$ analyses comparing the proportion of adult female polar bear locations on, near, and off the Cape Bathurst polynya and flaw lead of all bears, by reproductive status, and by month.

\begin{tabular}{|c|c|c|c|c|c|c|c|c|c|c|c|}
\hline & On & & & Near & & & Off & & & $\chi^{2}$ & $\mathrm{df}$ \\
\hline SOL & 10.5 & & & 73.8 & & & -60.6 & & & 5604 & 2 \\
\hline COY & -6.8 & & & 42.4 & & & -25.3 & & & 1829 & 2 \\
\hline YRLG & -7.3 & & & 57.4 & & & -36.1 & & & 3331 & 2 \\
\hline SUB_F & -3.7 & & & 30.3 & & & -19.8 & & & 928 & 2 \\
\hline SUB_M & 39.2 & & & 39.7 & & & -56.7 & & & 3212 & 2 \\
\hline \multirow[t]{2}{*}{ All } & 10.7 & & & 163.0 & & & -124.1 & & & 26761 & 2 \\
\hline & October & November & December & January & February & March & April & May & June & $\chi^{2}$ & $\mathrm{df}$ \\
\hline On & -56.0 & -15.4 & 4.6 & 8.1 & 14.2 & 17.4 & $-0.3^{a}$ & 43.2 & 63.0 & 7286 & 8 \\
\hline Near & -12.4 & -35.3 & -8.6 & $-1.5^{a}$ & 6.2 & -2.6 & 7.6 & $0.3^{a}$ & 45.2 & 2896 & 8 \\
\hline Off & 8.4 & 13.2 & 8.2 & 8.1 & 7.6 & 8.1 & 4.6 & -13.3 & -45.4 & 2460 & 8 \\
\hline
\end{tabular}

Note: Standardized residuals $>2$ are where bears are spending more time than expected, standardized residuals $<-2$ are where bears are spending less time than expected based on the habitat available. SOL, solitary adult females, COY, females with cub(s)-ofthe-year; YRLG, females with yearling(s); SUB_F, subadult females; and SUB_M, subadult males. All tests had a significance of $<0.001$

${ }^{a}$ Bears had the expected number of locations in the area at this time based on the habitat available.

maximum width, solitary adult bears used areas farthest from the CBP and subadult males used areas closest (Fig. 4A). Bears were closest to the CBP on days with a greater width (LME, $P<0.001$, Table S7 in Supplementary material $3^{1}$ ). When predicting bears distance to coast, bears were farthest from the coast at the beginning and end of the year (Fig. 4B), and on days with a greater maximum width (GLME, $P<0.001$, Table S7 in Supplementary material $3^{1}$ ). All bears used higher ice concentrations when farther from the CBP (Table 3), and when on narrower sections of the CBP (Fig. 5A). When examining selection of the $\mathrm{CBP}$, bears selected for intermediate CBP widths (Fig. 5B).

\section{Bear movements}

With the exception of subadult females' movement direction on the CBP, the distributions of movement direction relative to the CBP and turning angles followed bivariate von 
Fig. 4. Plots predicting Beaufort Sea polar bears' distance to (A) the Cape Bathurst Polynya and flaw lead, and (B) the coast with an interaction between date and reproductive status at a mean daily maximum width from October to June 2007-2014, on days with open water. COY, females with cub(s)-of-the-year; SOL, solitary female; SUB_F, subadult female; SUB_M, subadult male; and YRLG, females with yearling(s).

A

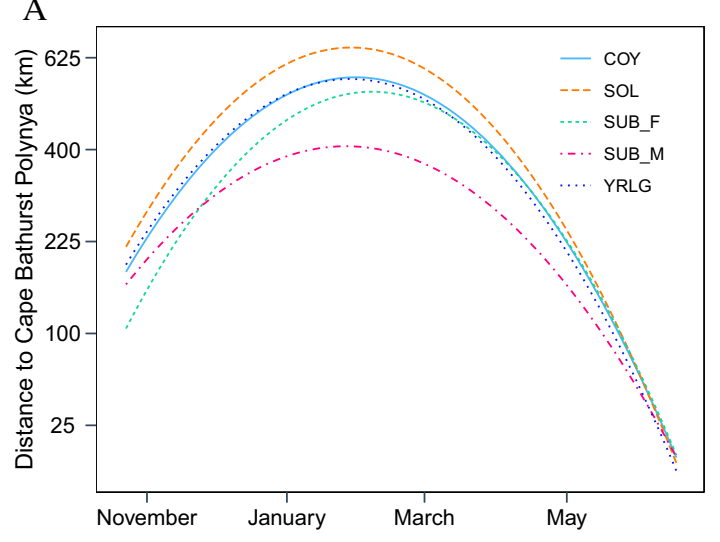

B

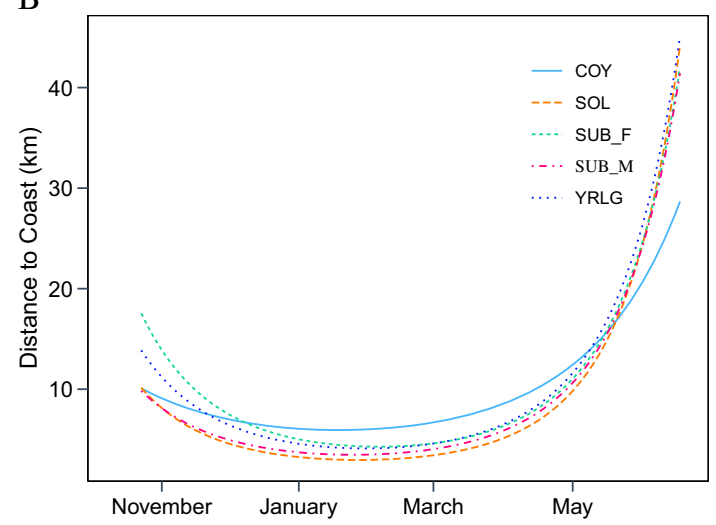

Table 3. Covariate coefficient estimates for generalized linear mixed effects (GLME) models predicting ice concentration used by polar bears, and crossing rate of the Cape Bathurst polynya and flaw lead (CBP; $\alpha=0.05$ ). Ice concentration was extracted from AMSRE, SSMIS, and AMRS2 satellite imagery (Spreen et al. 2008).

\begin{tabular}{llllllll}
\hline & & & \multicolumn{2}{l}{$95 \% \mathrm{CI}$} & \\
\cline { 5 - 6 } Dependent variable & Parameter & Estimate & SE & Lower & Upper & $p$ \\
\hline Ice concentration (GLME) & Distance to CBP & $1.4 \times 10^{-4}$ & $1.9 \times 10^{-6}$ & $1.4 \times 10^{-4}$ & $1.5 \times 10^{-4}$ & $<0.001$ \\
& Constant & 4.49 & 0.003 & 4.48 & 4.49 & $<0.001$ \\
\cline { 2 - 5 } CBP crossing (GLME) & Farthest side & -1.6 & 0.5 & -2.7 & -0.6 & $<0.01$ \\
& Mean width & -0.02 & 0.01 & -0.04 & -0.005 & $<0.05$ \\
& Intercept & -2.2 & 0.4 & -2.9 & -1.5 & $<0.001$ \\
\hline
\end{tabular}

Note: Distance to CBP is the shortest straight-line distance from the bears' location to the Cape Bathurst polynya or flaw lead. Farthest side refers to bears' trips (consecutive locations within $2.4 \mathrm{~km}$ from the $\mathrm{CBP}$ ) starting on the side of the CBP farthest from the coast. Mean width end is the mean width of the CBP for the duration of the trip.

Mises distributions (Figs. 6 and 7, Table S18 in Supplementary material $8^{1}$ ), and differed between reproductive groups and distance categories. When on the CBP, solitary females and females with YRLG moved more often towards and along the CBP than away from it; therefore, once on the CBP, bears continued moving towards the feature. Females with COY moved more often towards and away from the feature than along, and subadult males moved more often away from and along the feature than towards it. Subadult females had a uniform distribution of moves, representing random movement when on the CBP. When near the CBP, solitary bears, females with YRLG, and subadult females moved more often away from and towards the CBP than along, whereas females with COY and subadult males moved more often away from and along the feature than towards it. Off the CBP, all bears moved more often away and towards the CBP than along. All bears had predominantly low turning angles in all distance categories (Fig. 7).

FPT was calculated using a radius of $2 \mathrm{~km}$ (Fig. S2 in Supplementary material $6^{1}$ ) and 439 tracks from 78 bears ( $91 \%$ of locations) that were $26.3 \pm 1.5$ days long (range: 5.5-217.8 days). Mean FPT was $13.7 \pm 0.08 \mathrm{~h}$ (range: $0.6-346.3 \mathrm{~h} ; n=69$ 969). From October to June, FPT was 
Fig. 5. Plots predicting (A) ice concentrations polar bears used based on the width of the Cape Bathurst Polynya and flaw lead (CBP) when bears were $\leq 1$ median step length from the CBP and (B) polar bears' selection of the CBP from October to June 2007-2014.
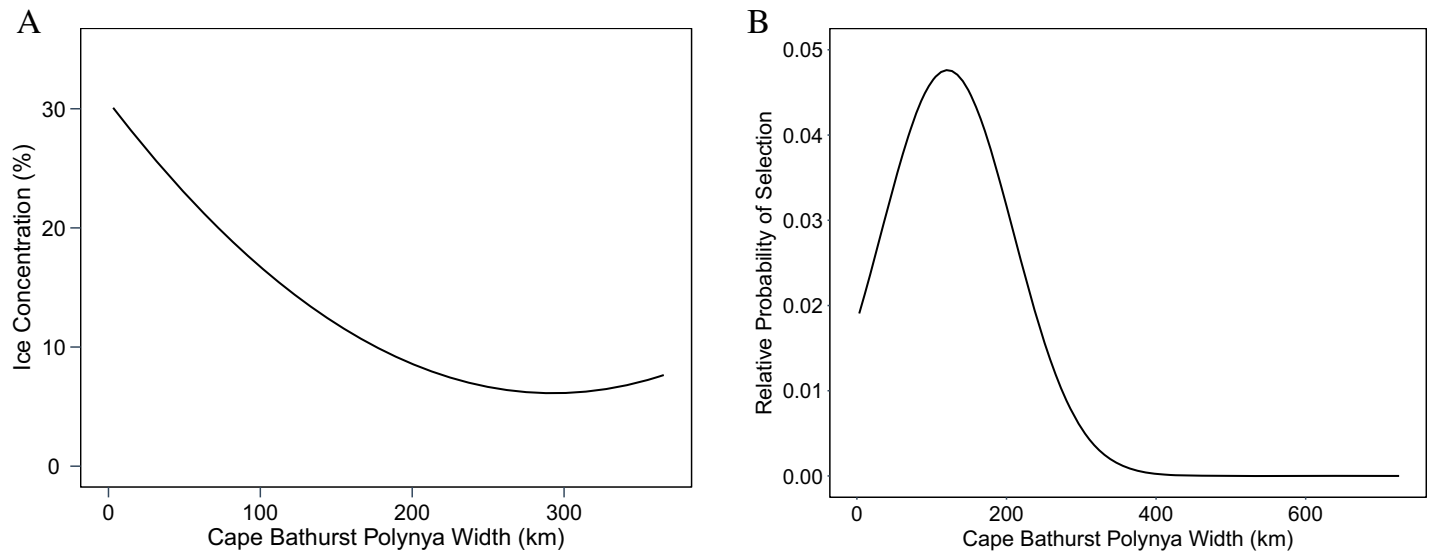

Fig. 6. Movement directions relative to the Cape Bathurst Polynya and flaw lead (CBP) of Beaufort Sea polar bears from October to June 2007-2014 on, near, and off the CBP. Relative movement directions were categorized into 3 groups: towards $\left(-45^{\circ} \leq \theta \leq 45^{\circ}\right)$, along $\left(-45^{\circ}>\theta>-135^{\circ}\right.$ and $\left.45^{\circ}<\theta<135^{\circ}\right)$, and away $\left(-135^{\circ} \leq \theta \geq 135^{\circ}\right)$ from the CBP. Grey bars represent the proportion of angles, and the solid black line represents the bivariate von Mises distribution with the best fit.
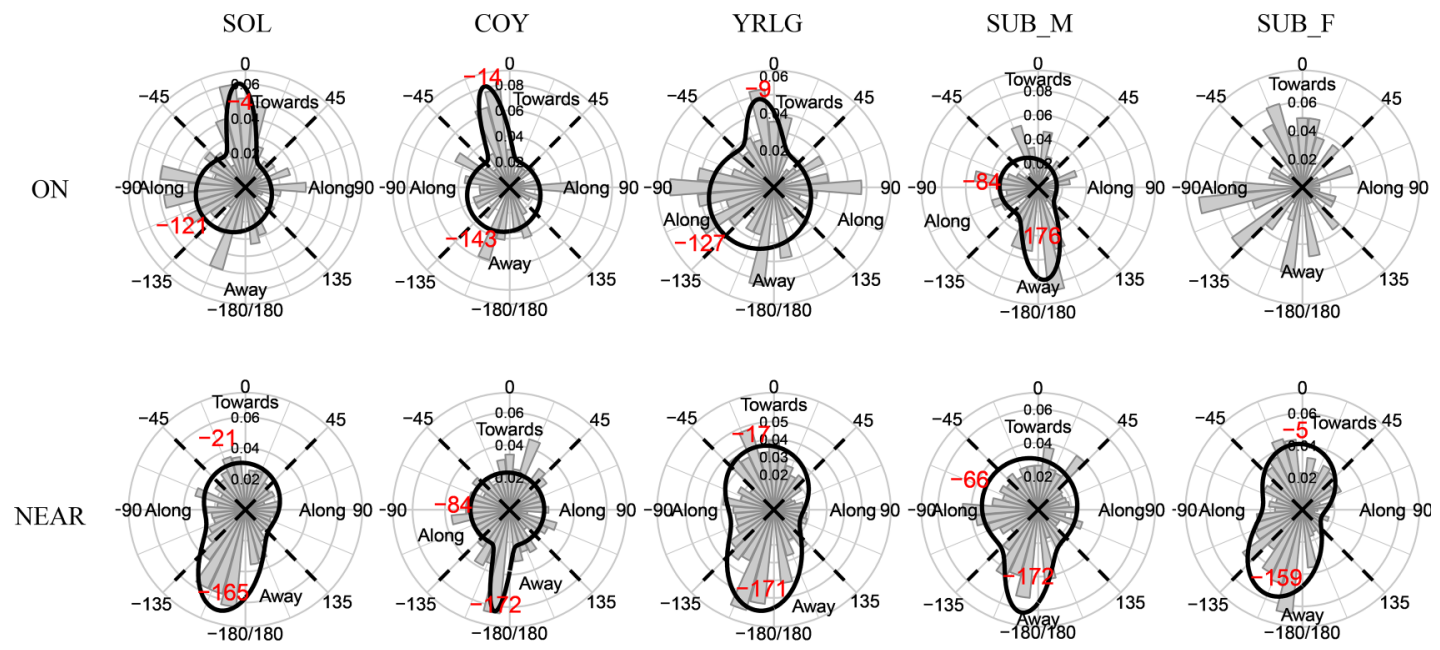

ALL

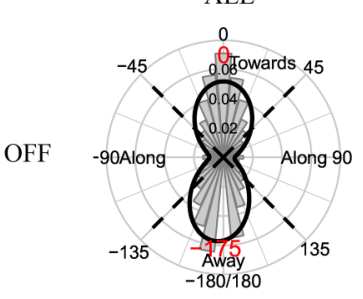

- Published by Canadian Science Publishing 
Fig. 7. Turning angles of Beaufort Sea polar bears from October-June, 2007-2014 on, near, and off the Cape Bathurst Polynya and flaw lead. Turning angles were categorized into 3 groups: low $\left(-45^{\circ} \leq \theta \leq 45^{\circ}\right)$, $\operatorname{turn}\left(-45^{\circ}>\theta>-135^{\circ}\right.$ and $\left.45^{\circ}<\theta<135^{\circ}\right)$, and reversal turn $\left(-135^{\circ} \leq \theta \geq 135^{\circ}\right)$. Grey bars represent the proportion of angles, and the solid black line represents the bivariate von Mises distribution with the best fit.

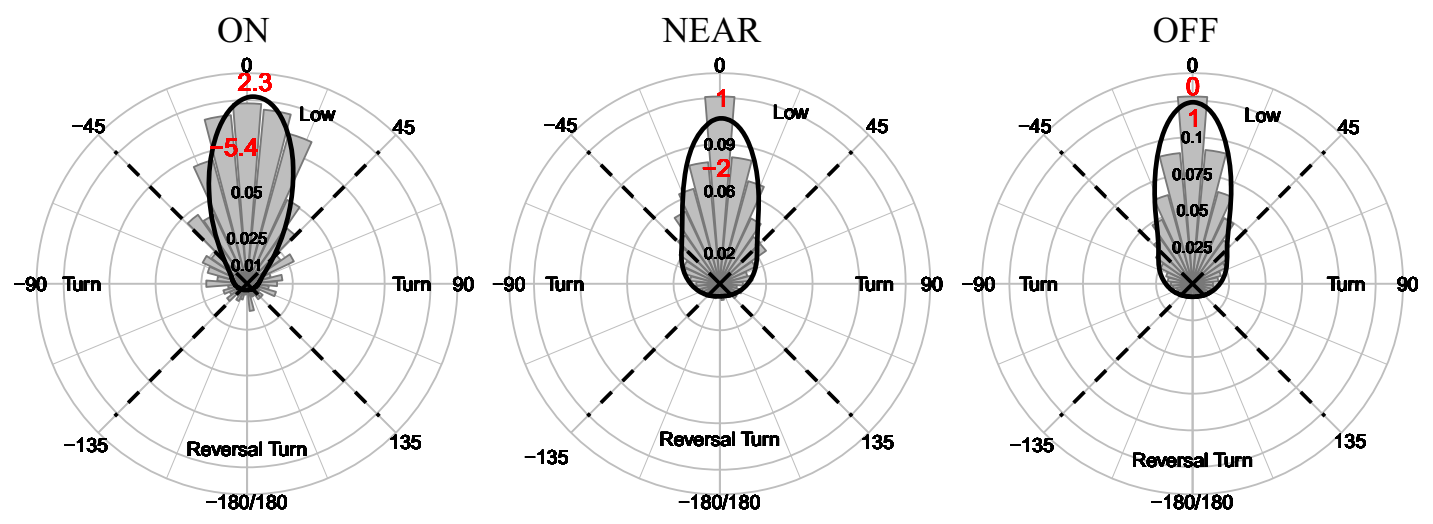

highest at intermediate distances from the CBP, indicating bears spent more time in this area, with differences in the effect of date on movement rates based on reproductive status (Fig. 8A,B). All bears had higher FPT towards the end of the study year, with females with COY and subadult females having the highest and lowest FPT, respectively. When on the CBP, females with offspring, and subadult females' FPT increased with increasing CBP width, whereas solitary females' and subadult males' FPT decreased with increasing CBP width (Fig. 8C).

Over the study, 62 bears had 367 trips ( $\geq 1$ consecutive location in the "on" category) on the CBP, and remained on the CBP for $9.7 \pm 1.0 \mathrm{~h}(4-216 \mathrm{~h})$. Bears crossed the CBP $8 \%$ (31/367) of the time. Of the 24 individuals that crossed the CBP, they crossed $1.3 \pm 0.2$ times (range: $1-4$ ) and spent $2.7 \pm 1.7 \mathrm{~h}$ (range: $0-52 \mathrm{~h}$ ) on the CBP before crossing. Bears were less likely to cross the CBP when the trip began on the side farthest from the coast, and they were less likely to cross the CBP when it was wider (Table 3).

\section{Discussion}

We found spatial and temporal variation, influenced by reproductive status, in the use and selection of the CBP and in polar bears movements relative to the features. Our findings were consistent with findings that polar bears in the Beaufort Sea remain close to the coast in winter/spring where waters are shallower and more productive but move farther offshore as ice retreats in summer (Stirling et al. 1993; Pongracz and Derocher 2017; Johnson and Derocher 2020). We found bears farthest from the coast in autumn and spring, when bears were also close to the CBP. Therefore, bears may not have moved closer to the CBP in autumn and spring, but instead the CBP edge moved closer to areas bears were using. Bears still used the CBP more frequently in autumn and spring, however, rather than moving away from the CBP edge.

A limitation of our study was that reproductive status of adult females was not conclusively determined after collaring, and reproductive success in the Beaufort Sea has been estimated at approximately 70\% (Rode et al. 2018), which might mean some bears were misclassified. Inferring reproductive status for the tracking period based on interbirth periods and movements representing denning behaviour, however, is commonly used (e.g., Johnson and Derocher 2020; Henderson et al. 2021). Furthermore, our study was 
Fig. 8. Plots predicting polar bears' $\log _{10}$-transformed first passage time in (A) based on an interaction between date and reproductive status at (B) a mean distance to the Cape Bathurst Polynya and flaw lead (CBP) from October to June 2007-2014, and (C) all bears on the CBP based width of the CBP. COY, females with cub(s)-of-theyear; SOL, solitary female; SUB_F, subadult female; SUB_M, subadult male; and YRLG, females with yearling(s).

A
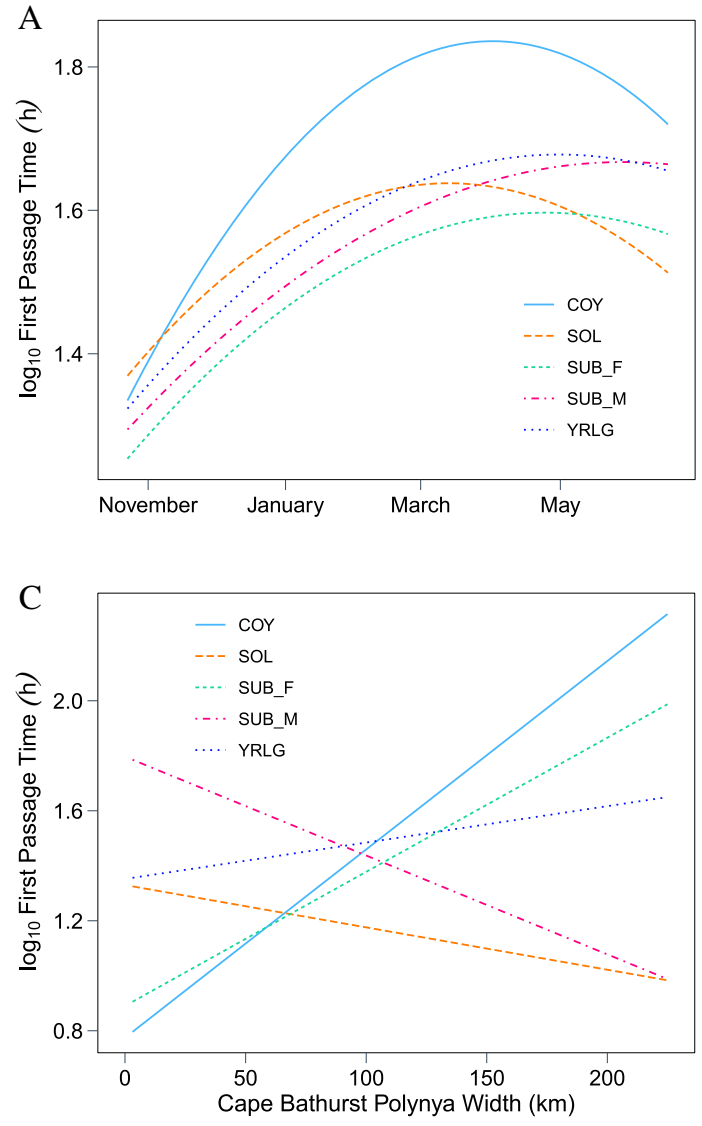

$\mathrm{B}$

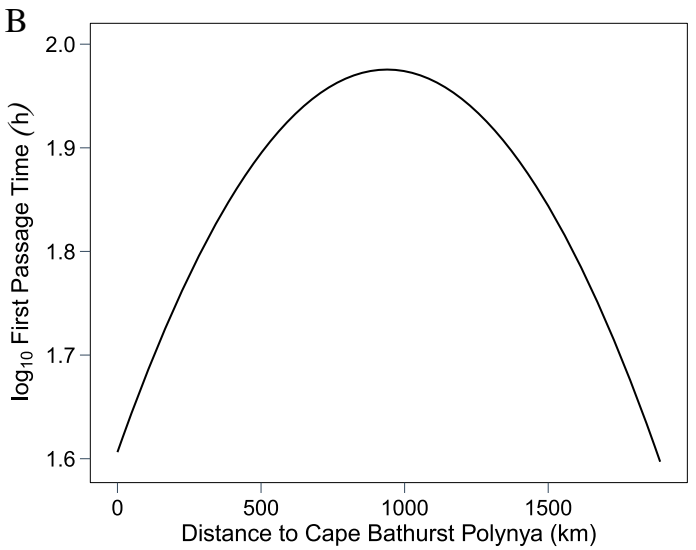

limited by the spatial resolution of the ice imagery, which might result in the underestimation of open water in areas where the width is $<3.25 \mathrm{~km}$. Using higher resolution imagery, however, can limit the temporal resolution (Henderson et al. 2021), and using imagery with near-daily resolution allows us to estimate the use, selection, and changes in movement for a greater number of bears.

Similar to polar bear use of the western Hudson Bay flaw lead (Henderson et al. 2021), Beaufort Sea solitary adult females used the CBP most frequently in spring, with width influencing bear use and movements. In western Hudson Bay, however, fewer bears used the flaw lead, and they were on average farther from the flaw lead in spring (Henderson et al. 2021) than Beaufort Sea bears were from the CBP. Hudson Bay is shallow across its whole area and, thus, polar bear prey are more widespread (Lunn et al. 1997; Chambellant et al. 2012) than the Beaufort Sea where prey are more abundant over the continental shelf (Stirling et al. 1977; Frost et al. 2004; Breed et al. 2018). Therefore, nearshore areas are likely more important for hunting in the Beaufort Sea (Johnson and Derocher 2020). In addition, we used AMSR imagery that had a more consistent temporal scale and covered a greater proportion of a bear's home range than synthetic aperture radar used by Henderson et al. (2021). The imagery we used may have allowed us to better measure polar bear use and 
movements over the entire home range, which might have contributed to detecting more bears on the CBP. The spatial resolution of AMSRE imagery, however, is coarser (Spreen et al. 2008), and narrower sections of the CBP, particularly in winter, might have been missed, which could have overestimated distance to the CBP.

Consistent with findings of Beaufort Sea bears using active ice and the ice edge in spring (Pilfold et al. 2014a; Reimer et al. 2019; Johnson and Derocher 2020), we found 79\% of bears used the CBP, primarily solitary females and subadult males that were found at a higher than expected frequency on the CBP in spring when the feature was more prominent. Leads can act as a concentrating feature for bears to make it easier to find mates (Stirling et al. 1993), therefore breeding bears may walk along the CBP more frequently in spring. Furthermore, solitary females and subadult males travelled faster with low turning angles along the feature as width increased. Bears may use the ice edge as a corridor to travel faster with low turning angles and increase prey encounter rates (Henderson et al. 2021), and hyperphagia in spring (Stirling and McEwan 1975; Ramsay and Stirling 1988) might increase use by solitary females and subadult males. Conversely, bears might conserve energy in winter by travelling slower when prey is less available (Henderson et al. 2021).

Females with offspring and subadult females, however, moved slower on wider sections of the CBP, with low turning angles, and were on the CBP less frequently than expected, suggesting that they found the area to be more challenging, possibly due to the lower ice concentration. Energetic output is higher in active and less consolidated ice (Mauritzen et al. 2003) such as that found along the CBP, and bears leave areas after feeding (Stirling 1974; Stirling and McEwan 1975; Smith 1980), therefore females with offspring and subadult females may move off the feature after encountering prey (Henderson et al. 2021) to prioritize energy conservation on more consolidated ice. Swimming is more energetically costly than travelling over ice (Fish 1996; Pagano et al. 2012; Griffen 2018); therefore, bears may also conserve energy by avoiding the CBP to prevent swimming where it is wider and has lower ice concentrations. Furthermore, females with COY walked towards and away from the CBP, suggesting they might only use the CBP to cross, or they might encounter the feature and leave, rather than use it. Cubs are at a higher risk of hypothermia while swimming (Blix and Lentfer 1979; Aars and Plumb 2010; Griffen 2018); therefore, females with offspring may avoid the CBP to lower the risk for cubs. Females with COY might also avoid the CBP to avoid intraspecific interactions (Pilfold et al. 2014a; Henderson et al. 2021).

Bears were less likely to cross the CBP from the pack ice towards the coast. In the Southern Beaufort Sea subpopulation, 73\% of the bears summer on pack ice as opposed to land (Pongracz and Derocher 2017); therefore, fewer crossings towards land would occur in spring, but some spring crossings were likely associated with a bear's eventual summering location. Bears were also less likely to cross when the CBP was wider; they crossed at sections that were 53\% narrower than sections they did not cross. Although bears can swim long distances ( $>50 \mathrm{~km}$; Pagano et al. 2012; Pilfold et al. 2017), most long distance swims in the Beaufort Sea start and end in pack ice (Pilfold et al. 2017), which is higher quality habitat (Pilfold et al. 2014a). Only 16\% of crossings required a long-distance swim, and only one long distance crossing was from pack ice towards the coast, suggesting bears may avoid crossing the CBP and leaving pack ice when it requires a long-distance swim. Long distance swims can negatively affect bears' body condition and cub survival (Fish 1996; Durner et al. 2011; Pagano et al. 2012; Griffen 2018); therefore, bears may be less likely to cross from pack ice when the CBP is wider because of the higher energetic cost to return. When the CBP is narrower, however, crossing to return to the pack ice would not be as energetically costly.

Although Beaufort Sea bears swim long distances more frequently than western Hudson Bay bears, (Pilfold et al. 2017), we found that Beaufort Sea bears crossed the CBP less frequently than bears crossed the western Hudson Bay flaw lead (Henderson et al. 2021). 
Western Hudson Bay bears used narrower sections of the western Hudson Bay flaw lead (Henderson et al. 2021) than Beaufort Sea bears used of the CBP; therefore, remaining in pack ice rather than crossing might be more important for Beaufort Sea bears because the return crossing of the wider CBP would be more energetically costly than in western Hudson Bay.

Arctic sea ice is declining due to climate warming (Comiso 2012; Laxon et al. 2013), with a trend of an earlier break-up and later freeze-up (Johnson and Eicken 2016). An earlier breakup and later freeze-up might negatively affect access to land denning habitat for pregnant females (Amstrup and Gardner 1994; Florko et al. 2020a) or landfast ice as the CBP widens earlier, and drives bears farther offshore for longer where access to prey is diminished (Stirling et al. 1977; Frost et al. 2004; Breed et al. 2018), lengthening the offshore fast (Whiteman et al. 2018). Furthermore, Arctic habitats are becoming more fragmented with climate warming (Sahanatien and Derocher 2012), which might further decrease ice concentrations making the CBP more challenging, particularly for bears with small cubs as less consolidated ice increases swim frequency/duration and energetic costs (Mauritzen et al. 2003; Derocher et al. 2004). With earlier break-up, however, bears are predicted to use active ice more frequently as bears prioritize hunting over safety (Reimer et al. 2019), which might bring more females with offspring to the CBP, or might heighten the importance of the CBP for bears earlier in the season. Understanding polar bear use of prominent habitat features could help with predicting their behavioural responses to habitat changes due to climate warming. Our analyses suggest that the Cape Bathurst polynya and flaw lead system are a significant feature that affects the ecology of polar bears by acting as a corridor and hunting habitat but also as a barrier to movement.

\section{Acknowledgements}

Funding and logistical support was provided by Canadian Association of Zoos and Aquariums, Canadian Wildlife Federation, Environment and Climate Change Canada, Hauser Bears, Natural Sciences and Engineering Research Council of Canada, The Ocean Foundation, Polar Bears International, Polar Continental Shelf Project, Quark Expeditions, United States Department of the Interior (Bureau of Ocean Energy Management), and World Wildlife Fund Canada. We acknowledge the use of imagery from the National Aeronautics and Space Administration Worldview application (https://worldview.earthdata.nasa.gov/), part of the Earth Observing System Data and Information System (EOSDIS).

\section{References}

Aars, J., and Plumb, A. 2010. Polar bear cubs may reduce chilling from icy water by sitting on mother's back. Polar Biol. 33: 557-559. doi: 10.1007/s00300-009-0721-3.

Agostinelli, C., and Lund, U. 2017. R package 'circular': Circular statistics (version 0.4-93). Available from https:/| r-forge.r-project.org/projects/circular/

Agresti, A. 2018. Contingency tables. An introduction to categorical data analysis. 2nd ed. John Wiley and Sons, Hoboken, New Jersey.

Amstrup, S.C., and Gardner, C. 1994. Polar bear maternity denning in the Beaufort Sea. J. Wildl. Manag., 1-10. doi: $10.2307 / 3809542$.

Amstrup, S.C., Durner, G.M., Stirling, I., Lunn, N.J., and Messier, F. 2000. Movements and distribution of polar bears in the Beaufort Sea. Can. J. Zool. 78: 948-966. doi: 10.1139/z00-016.

Arrigo, K.R., and Van Dijken, G.L. 2004. Annual cycles of sea ice and phytoplankton in Cape Bathurst polynya, southeastern Beaufort Sea, Canadian Arctic. Geophys. Res. Lett. 31: L08304. doi: 10.1029/2003GL018978.

Auger-Méthé, M., Lewis, M.A., and Derocher, A.E. 2016. Home ranges in moving habitats: Polar bears and sea ice. Ecography 39: 26-35. doi: 10.1111/ecog.01260.

Barber, D.G., and Massom, R.A. 2007. Chapter 1 the role of sea ice in Arctic and Antarctic polynyas. In Polynyas: Windows to the world. Edited by W.O. Smith and D.G. Barber. Elsevier, Amsterdam.

Bates, D., Mächler, M., Bolker, B., and Walker, S. 2015. Fitting linear mixed-effects models using lme4. J. Stat. Softw. 67(4): 1-48. doi: $10.18637 / j s s . v 067 . i 01$

Bivand, R., and Rundel, C. 2019. Rgeos: Interface to geometry engine - open source ('geos'). R package version 0.5-2. Available from https://CRAN.R-project.org/package=rgeos 
Blix, A.S., and Lentfer, J.W. 1979. Modes of thermal protection in polar bear cubs-at birth and on emergence from the den. Am. J. Physiol. Regul. Integr. Comp. Physiol. 236: R67-R74. doi: 10.1152/ajpregu.1979.236.1.R67.

Breed, G.A., Cameron, M.F., Ver Hoef, J.M., Boveng, P.L., Whiting, A., and Frost, K.J. 2018. Seasonal sea ice dynamics drive movement and migration of juvenile bearded seals Erignathus barbatus. Mar. Ecol. Prog. Ser. 600: 223-237. doi: $10.3354 /$ meps12659.

Bromaghin, J.F., Mcdonald, T.L., Stirling, I., Derocher, A.E., Richardson, E.S., Regehr, E.V., et al. 2015. Polar bear population dynamics in the southern Beaufort Sea during a period of sea ice decline. Ecol. Appl. 25: 634-651. doi: 10.1890/14-1129.1. PMID: 26214910.

Burnham, K.P., and Anderson, D.R. 2002. Model selection and multimodel inference: A practical informationtheoretic approach. Springer: New York.

Calenge, C. 2006. The package "adehabitat" for the R software: A tool for the analysis of space and habitat use by animals. Ecol. Model. 197: 516-519. doi: 10.1016/j.ecolmodel.2006.03.017.

Calvert, W., and Ramsay, M.A. 1998. Evaluation of age determination of polar bears by counts of cementum growth layer groups. Ursus 10: 449-453. Available from http://www.jstor.org/stable/3873156.

Carmack, E.C., and Macdonald, R.W. 2002. Oceanography of the Canadian shelf of the Beaufort Sea: A setting for marine life. Arctic 55: 29-45. doi: 10.14430/arctic733.

Chambellant, M., Lunn, N.J., and Ferguson, S.H. 2012. Temporal variation in distribution and density of iceobligated seals in western Hudson Bay, Canada. Polar Biol. 35: 1105-1117. doi: 10.1007/s00300-012-1159-6.

Citta, J.J., Quakenbush, L.T., Okkonen, S.R., Druckenmiller, M.L., Maslowski, W., Clement-Kinney, J., et al. 2015. Ecological characteristics of core-use areas used by Bering-Chukchi-Beaufort (BCB) bowhead whales, 2006-2012. Prog. Oceanogr. 136: 201-222. doi: 10.1016/j.pocean.2014.08.012.

Comiso, J.C. 2012. Large decadal decline of the Arctic multiyear ice cover. J. Clim. 25: 1176-1193. doi: 10.1175/JCLI-D-1100113.1.

Derocher, A.E., Lunn, N.J., and Stirling, I. 2004. Polar bears in a warming climate. Integr. Comp. Biol. 44: 163-176. doi: 10.1093/icb/44.2.163. PMID: 21680496.

Durner, G.M., Whiteman, J.P., Harlow, H.J., Amstrup, S.C., Regehr, E.V., and Ben-David, M. 2011. Consequences of long-distance swimming and travel over deep-water pack ice for a female polar bear during a year of extreme sea ice retreat. Polar Biol. 34: 975-984. doi: 10.1007/s00300-010-0953-2.

Fauchald, P., and Tveraa, T. 2003. Using first-passage time in the analysis of area-restricted search and habitat selection. Ecology 84: 282-288. doi: 10.1890/0012-9658(2003)084[0282:UFPTIT]2.0.CO;2.

Fauchald, P., and Tveraa, T. 2006. Hierarchical patch dynamics and animal movement pattern. Oecologia 149: 383-395. doi: 10.1007/s00442-006-0463-7. PMID: 16794832.

Fish, F.E. 1996. Transitions from drag-based to lift-based propulsion in mammalian swimming. Am. Zool. 36: 628-641. doi: 10.1093/icb/36.6.628.

Florko, K.R., Derocher, A.E., Breiter, C.J.C., Maha, G., Daryll, H., Higdon, J.W., et al. 2020a. Polar bear denning distribution in the Canadian Arctic. Polar Biol. 43: 617-621. doi: 10.1007/s00300-020-02657-8.

Florko, K.R., Thiemann, G.W., and Bromaghin, J.F. 2020b. Drivers and consequences of apex predator diet composition in the Canadian Beaufort Sea. Oecologia, 1-13. doi: 10.1007/s00442-020-04747-0.

Freitas, C. 2012. Argosfilter: Argos locations filter. R package version 0.63. Available from https://CRAN.Rproject.org/package=argosfilter

Freitas, C., Kovacs, K.M., Lydersen, C., and Ims, R.A. 2008. A novel method for quantifying habitat selection and predicting habitat use. J. Appl. Ecol. 45: 1213-1220. doi: 10.1111/j.1365-2664.2008.01505.x.

Frost, K.J., Lowry, L.F., Pendleton, G., and Nute, H.R. 2004. Factors affecting the observed densities of ringed seals, Phoca hispida, in the Alaskan Beaufort Sea, 1996-99. Arctic 57: 115-128. doi: 10.14430/arctic489.

Gilchrist, H.G., and Robertson, G.J. 2000. Observations of marine birds and mammals wintering at polynyas and ice edges in the belcher islands, Nunavut, Canada. Arctic 53: 61-68. doi: 10.14430/arctic835.

Griffen, B.D. 2018. Modeling the metabolic costs of swimming in polar bears (Ursus maritimus). Polar Biol. 41: 491-503. doi: 10.1007/s00300-017-2209-x.

Heinrichs, J.F., Cavalieri, D.J., and Markus, T. 2006. Assessment of the AMSR-E sea ice concentration product at the ice edge using RADARSAT-1 and modis imagery. IEEE Trans. Geosci. Rem. Sens. 44: 3070-3080. doi: 10.1109/ TGRS.2006.880622.

Henderson, E.M., Derocher, A.E., Lunn, N.J., Montpetit, B., Merrill, E.H., and Richardson, E.S. 2021. Polar bear Ursus maritimus use of the western Hudson Bay flaw lead. Mar. Ecol. Prog. Ser. 664: 227-242. doi: 10.3354/meps13642.

Hijmans, R.J. 2019a. Geosphere: Spherical trigonometry. R package version 1.5-10. Available from https://CRAN.Rproject.org/package=geosphere.

Hijmans, R.J. 2019b. Raster: Geographic data analysis and modeling. R package version 3.0-7. Available from https:// CRAN.R-project.org/package=raster.

Hurford, A. 2009. GPS measurement error gives rise to spurious $180^{\circ}$ turning angles and strong directional biases in animal movement data. PLoS ONE 4: e5632. doi: 10.1371/journal.pone.0005632. PMID: 19479067.

Johnson, A.C., and Derocher, A.E. 2020. Variation in habitat use of Beaufort Sea polar bears. Polar Biol. 43: 1247-1260. doi: 10.1007/s00300-020-02705-3.

Johnson, D.S., and London, J.M. 2018. Crawl: An R package for fitting continuous-time correlated random walk models to animal movement data. Zenodo.

Johnson, D.S., London, J.M., Lea, M.-A., and Durban, J.W. 2008. Continuous-time correlated random walk model for animal telemetry data. Ecology 89: 1208-1215. doi: 10.1890/07-1032.1. PMID: 18543615. 
Johnson, M., and Eicken, H. 2016. Estimating Arctic sea-ice freeze-up and break-up from the satellite record: A comparison of different approaches in the Chukchi and Beaufort Seas. Elem. Sci. Anth. 4: 000124. doi: 10.12952/ journal.elementa.000124.

Laidre, K.L., Stirling, I., Lowry, L.F., Wiig, Ø., Heide-Jørgensen, M.P., and Ferguson, S.H. 2008. Quantifying the sensitivity of Arctic marine mammals to climate-induced habitat change. Ecol. Appl. 18: S97-S125. doi: 10.1890/060546.1. PMID: 18494365.

Laxon, S.W., Giles, K.A., Ridout, A.L., Wingham, D.J., Willatt, R., Cullen, R., et al. 2013. Cryosat-2 estimates of Arctic sea ice thickness and volume. Geophys. Res. Lett. 40: 732-737. doi: 10.1002/grl.50193.

Li, J., and Heap, A.D. 2011. A review of comparative studies of spatial interpolation methods in environmental sciences: Performance and impact factors. Ecol. Inform. 6: 228-241. doi: 10.1016/j.ecoinf.2010.12.003.

Lønø, O. 1970. The polar bear (Ursus maritimus Phipps) in the Svalbard area. Norsk Polarinstitutt Skrifter 149: 1-115. Available from https://brage.npolar.no/npolar-xmlui/bitstream/handle/11250/173883/Skrifter149.pdf.

Lunn, N.J., Stirling, I., and Nowicki, S.N. 1997. Distribution and abundance of ringed (Phoca hispida) and bearded seals (Erignathus barbatus) in western Hudson Bay. Can. J. Fish. Aquat. Sci. 54: 914-921. doi: 10.1139/f96-346.

Mallory, M.L., Gaston, A.J., Provencher, J.F., Wong, S.N., Anderson, C., Elliott, K.H., et al. 2019. Identifying key marine habitat sites for seabirds and sea ducks in the Canadian Arctic. Environ. Rev. 27: 215-240. doi: 10.1139/ er-2018-0067.

Mauritzen, M., Belikov, S.E., Boltunov, A.N., Derocher, A.E., Hansen, E., Ims, R.A., et al. 2003. Functional responses in polar bear habitat selection. Oikos 100: 112-124. doi: 10.1034/j.1600-0706.2003.12056.x.

McKenzie, H.W., Merrill, E.H., Spiteri, R.J., and Lewis, M.A. 2012. How linear features alter predator movement and the functional response. Interface Focus 2: 205-216. doi: 10.1098/rsfs.2011.0086.

McLean, D.J., and Skowron Volponi, M.A. 2018. Trajr: An R package for characterisation of animal trajectories. Ethology 124: 440-448. doi: 10.1111/eth.12739.

Muggeo, V.M. 2003. Estimating regression models with unknown break-points. Stat. Med. 22: 3055-3071. doi: 10.1002/sim.1545. PMID: 12973787.

Muggeo, V.M. 2008. Segmented: An R package to fit regression models with broken-line relationships. R News 8(1): 20-25. Available from https:/cran.r-project.org/doc/Rnews/

Muggeo, V.M. 2016. Testing with a nuisance parameter present only under the alternative: A score-based approach with application to segmented modelling. J. Stat. Comput. Simul. 86: 3059-3067. doi: 10.1080/ 00949655.2016 .1149855$.

Muggeo, V.M. 2017. Interval estimation for the breakpoint in segmented regression: A smoothed score-based approach. Aus. NZ J. Stat. 59: 311-322. doi: 10.1111/anzs.12200.

NASA. 2018. NASA worldview application. Available from https://worldview.earthdata.nasa.gov [accessed 23 October 2016].

Pagano, A.M., Durner, G.M., Amstrup, S., Simac, K., and York, G. 2012. Long-distance swimming by polar bears (Ursus maritimus) of the southern Beaufort Sea during years of extensive open water. Can. J. Zool. 90: 663-676. doi: 10.1139/z2012-033.

Parks, E.K., Derocher, A.E., and Lunn, N.J. 2006. Seasonal and annual movement patterns of polar bears on the sea ice of Hudson Bay. Can. J. Zool. 84: 1281-1294. doi: 10.1139/z06-115.

Pilfold, N.W., Derocher, A.E., and Richardson, E. 2014a. Influence of intraspecific competition on the distribution of a wide-ranging, non-territorial carnivore. Glob. Ecol. Biogeogr. 23: 425-435. doi: 10.1111/geb.12112.

Pilfold, N.W., Derocher, A.E., Stirling, I., and Richardson, E. 2014b. Polar bear predatory behaviour reveals seascape distribution of ringed seal lairs. Popul. Ecol. 56: 129-138. doi: 10.1007/s10144-013-0396-z.

Pilfold, N.W., Mccall, A., Derocher, A.E., Lunn, N.J., and Richardson, E. 2017. Migratory response of polar bears to sea ice loss: To swim or not to swim. Ecography 40: 189-199. doi: 10.1111/ecog.02109.

Pongracz, J.D., and Derocher, A.E. 2017. Summer refugia of polar bears (Ursus maritimus) in the southern Beaufort Sea. Polar Biol. 40: 753-763. 10.1007/s00300-016-1997-8.

Qgis Development Team 2019. Qgis geographic information system. Available from http://qgis.osgeo.org

R Core Team 2019. R: A language and environment for statistical computing. Available from https://www.Rproject.org/

Ramsay, M.A., and Stirling, I. 1986. On the mating system of polar bears. Can. J. Zool. 64: 2142-2151. doi: 10.1139/z86329.

Ramsay, M.A., and Stirling, I. 1988. Reproductive biology and ecology of female polar bears (Ursus maritimus). J. Zool. 214: 601-633. doi: 10.1111/j.1469-7998.1988.tb03762.x.

Reimer, J.R., Mangel, M., Derocher, A.E., and Lewis, M.A. 2019. Modeling optimal responses and fitness consequences in a changing Arctic. Glob. Change Biol. 25: 3450-3461. doi: 10.1111/gcb.14681.

Rode, K.D., Olson, J., Eggett, D., Douglas, D.C., Durner, G.M., Atwood, T.C., et al. 2018. Den phenology and reproductive success of polar bears in a changing climate. J. Mammal. 99: 16-26. doi: 10.1093/jmammal/gyx181.

Sahanatien, V., and Derocher, A.E. 2012. Monitoring sea ice habitat fragmentation for polar bear conservation. Anim. Conserv. 15: 397-406. doi: 10.1111/j.1469-1795.2012.00529.x.

Sandvik, B. 2009. World borders dataset, Thematic Mapping. Viewed September 16, 2021. Available from http:// thematicmapping.org/downloads/world_borders.php

Schliebe, S., Rode, K., Gleason, J., Wilder, J., Proffitt, K., Evans, T., and Miller, S. 2008. Effects of sea ice extent and food availability on spatial and temporal distribution of polar bears during the fall open-water period in the southern Beaufort Sea. Polar Biol. 31: 999-1010. doi: 10.1007/s00300-008-0439-7. 
Sharma, G.D. 1979. Beaufort Sea shelf: Hydrographic, sedimentary, and geochemical environment. In The Alaskan shelf, Edited by G. Sharma, Springer, New York.

Smith, M., and Rigby, B. 1981. Distribution of polynyas in the Canadian Arctic. In Polynyas in the Canadian Arctic. Edited by I. Stirling and H. Cleator. Canadian Wildlife Service Occasional Paper 45.

Smith, S.D., Muench, R.D., and Pease, C.H. 1990. Polynyas and leads: An overview of physical processes and environment. J. Geophys. Res. 95: 9461-9479. doi: 10.1029/JC095iC06p09461.

Smith, T.G. 1980. Polar bear predation of ringed and bearded seals in the land-fast sea ice habitat. Can. J. Zool. 58: 2201-2209. doi: 10.1139/z80-302.

Spreen, G., Kaleschke, L., and Heygster, G. 2008. Sea ice remote sensing using AMSR-E 89-GHz channels. J. Geophys. Res. 113: C02S03. doi: 10.1029/2005JC003384

Stirling, I. 1974. Midsummer observations on the behavior of wild polar bears (Ursus maritimus). Can. J. Zool. 52: 1191-1198. doi: 10.1139/z74-157.

Stirling, I. 1980. The biological importance of polynyas in the Canadian Arctic. Arctic 33: 303-315. doi: 10.14430/ arctic2563.

Stirling, I. 1997. The importance of polynyas, ice edges, and leads to marine mammals and birds. J. Mar. Syst. 10: 9-21. doi: 10.1016/S0924-7963(96)00054-1.

Stirling, I., and McEwan, E.H. 1975. The caloric value of whole ringed seals (Phoca hispida) in relation to polar bear (Ursus maritimus) ecology and hunting behavior. Can. J. Zool. 53: 1021-1027. doi: 10.1139/z75-117. PMID: 1167176.

Stirling, I., Archibald, W.R., and Demaster, D. 1977. Distribution and abundance of seals in the eastern Beaufort Sea. Can. J. Fish. Aquat. Sci. 34: 976-988. doi: 10.1139/f77-150.

Stirling, I., Cleator, H., and Boyd, H. 1981. Polynyas in the Canadian Arctic, Environment Canada.

Stirling, I., Spencer, C., and Andriashek, D. 1989. Immobilization of polar bears (Ursus maritimus) with telazol in the Canadian Arctic. J. Wildl. Dis. 25: 159-168. doi: 10.7589/0090-3558-25.2.159. PMID: 2716095.

Stirling, I., Andriashek, D., and Calvert, W. 1993. Habitat preferences of polar bears in the western Canadian Arctic in late winter and spring. Polar Rec. 29: 13-24. doi: 10.1017/S0032247400023172.

Stirling, I., Mcdonald, T.L., Richardson, E.S., Regehr, E.V., and Amstrup, S.C. 2011. Polar bear population status in the northern Beaufort Sea, Canada, 1971-2006. Ecol. Appl. 21: 859-876. doi: 10.1890/10-0849.1. PMID: 21639050.

Togunov, R.R., Derocher, A.E., and Lunn, N.J. 2017. Windscapes and olfactory foraging in a large carnivore. Sci. Rep. 7: 46332. doi: 10.1038/srep46332. PMID: 28402340.

Togunov, R.R., Derocher, A.E., and Lunn, N.J. 2018. Corrigendum: Windscapes and olfactory foraging in a large carnivore. Sci. Rep. 8: 46968. doi: 10.1038/srep46968. PMID: 29849097.

Togunov, R.R., Klappstein, N.J., Lunn, N.J., Derocher, A.E., and Auger-Méthé, M. 2020. Opportunistic evaluation of modelled sea ice drift using passively drifting telemetry collars in Hudson Bay, Canada. TC 14: 1937-1950. doi: 10.5194/tc-14-1937-2020.

Tomkiewicz, S.M., Fuller, M.R., Kie, J.G., and Bates, K.K. 2010. Global positioning system and associated technologies in animal behaviour and ecological research. Philos. Trans. R. Soc. Lond. B. Biol. Sci. 365: 2163-2176. doi: 10.1098/ rstb.2010.0090. PMID: 20566494.

Tschudi, M., Meier, W.N.J., Stewart, S., Fowler, C., and Maslanik, J. 2019. Polar pathfinder daily $25 \mathrm{~km}$ ease-grid sea ice motion vectors. Version 4.1. December 2009 - May 2018. National Snow and Ice Data Center Boulder, Colorado USA. doi: 10.5067/INAWUWO7QH7B.

Whiteman, J.P., Harlow, H.J., Durner, G.M., Regehr, E.V., Amstrup, S.C., and Ben-David, M. 2018. Phenotypic plasticity and climate change: Can polar bears respond to longer Arctic summers with an adaptive fast? Oecologia 186: 369-381. doi: 10.1007/s00442-017-4023-0. PMID: 29197040. 